\title{
Pengaruh Ukuran Perusahaan, Corporate Social Responsibility, Profitabilitas dan Leverage pada Tax Avoidance
}

\author{
I Gusti Ayu Dwi Cahya Dewanti ${ }^{1}$ \\ I Ketut Sujana ${ }^{2}$ \\ ${ }^{1,2}$ Fakultas Ekonomi dan Bisnis Universitas Udayana (Unud), Bali, Indonesia \\ e-mail: cahya406@gmail.com
}

\begin{abstract}
ABSTRAK
Hasil penelitian menunjukkan bahwa ukuran perusahaan tidak berpengaruh pada tax avoidance karena besar kecilnya suatu perusahaan yang diukur melalui total aset yang dimiliki tidak memengaruhi keputusan perusahaan melakukan tindakan tax avoidance. Leverage tidak berpengaruh pada tax avoidance karena semakin tinggi tingkat hutang suatu perusahaan, maka tidak akan memengaruhi adanya praktik tax avoidance. Profitabilitas berpengaruh negatif pada tax avoidance karena semakin tinggi nilai profitabilitas perusahaan maka kecenderungan perusahaan melakukan tindakan tax avoidance semakin rendah. CSR berpengaruh negatif pada tax avoidance hal ini sesuai dengan teori legitimasi yang menyatakan bahwa perusahaan dalam mempertahankan kelangsungan hidupnya selalu berupaya agar mendapatkan legitimasi atau pengakuan baik dari para stakeholder nya. Semakin tinggi tingkat pengungkapan CSR suatu perusahaan maka perusahaan semakin menghindari adanya tindakan tax avoidance.
\end{abstract}

Kata kunci: Ukuran perusahaan, corporate social responsibility, profitabilitas, leverage, tax avoidance.

\begin{abstract}
The results of the study show that firm size of company does not affect tax avoidance because the size of a company that is measured through total assets owned does not affect the company's decision to take tax avoidance actions. Leverage does not affect tax avoidance because the higher the level of debt of a company, it will not affect the practice of tax avoidance. Profitability has a negative effect on tax avoidance because the higher the value of corporate profitability, the lower the tendency for companies to take tax avoidance actions. CSR has a negative effect on tax avoidance, this is in accordance with the legitimacy theory which states that the company in maintaining its survival always strives to gain legitimacy or good recognition from its stakeholders. The higher the level of CSR disclosure of a company, the more the company avoids the existence of tax avoidance actions.
\end{abstract}

Keywords: Company size, corporate social responsibility, profitability, leverage, tax avoidance.

\section{PENDAHULUAN}

Pajak merupakan salah satu sumber pendapatan negara yang sangat besar. Manfaat pajak yaitu untuk meningkatkan kesejahteraan masyarakat dan mendukung kegiatan pembangunan nasional suatu negara, oleh karena itu 
pemungutan pajak dapat dipaksakan berdasarkan Undang-undang Perpajakan yang berlaku. Pemerintah terus berupaya untuk memperbaiki sistem perpajakan menjadi lebih baik dalam rangka mewujudkan pembangunan nasional dan mensejahterakan seluruh masyarakat Indonesia. Hal ini tentunya tidaklah mudah karena pembangunan tersebut membutuhkan dana yang tidaklah sedikit. Maka dari itu, pemerintah membuat kebijakan-kebijakan mengenai pajak sehingga penerimaan pajak semakin besar dan pembangunan nasional pun bisa terlaksana dengan baik (Darmayanti, 2019).

Pemerintah dan wajib pajak mempunyai kepentingan yang berbeda dalam pelaksanaan pemungutan pajak. Pemerintah ingin terus meningkatkan atau mengoptimalkan penerimaan negara melalui pajak guna membiayai penyelenggaraan negara, sedangkan sebagian besar wajib pajak berusaha untuk membayar pajak seminimal mungkin karena dengan membayar pajak akan mengurangi pendapatan atau laba (Chen et al., 2010)

Salah satu wajib pajak di Indonesia adalah perusahaan. Setiap wajib pajak diwajibkan untuk membayar iuran pajak kepada Negara, tetapi bagi perusahaan pajak merupakan beban karena dapat mengurangi laba bersih perusahaan, terlebih lagi tidak mendapatkan imbalan langsung ketika membayar pajak oleh karena itu, hampir sebagian besar perusahaan tidak ada yang sukarela membayar pajak (Dowling \& Pfeffer, 1975). Perusahaan membayar pajak karena sifatnya yang memaksa, apabila perusahaan tidak membayar pajak maka akan terkena sanksi yang nantinya akan merugikan perusahaan (Dyreng at al., 2008). Hal itulah yang menyebabkan banyak 
perusahaan melakukan penghindaran pajak agar perusahaan tetap membayar pajak tetapi dengan meminimalisir beban pajak yang akan dibayarkan.

Menurut Darmawan \& Sukartha (2014) tindakan yang dilakukan perusahaan dalam meminimalkan beban pajak dapat berupa tindakan yang legal (tax avoidance) maupun ilegal (tax evasion). Tax avoidance adalah salah satu cara untuk menghindari pajak secara legal yang tidak melanggar peraturan perpajakan. Penghindaran pajak ini dapat dikatakan persoalan yang rumit dan unik karena disatu sisi penghindaran pajak diperpolehkan, tetapi di sisi lain hal ini tidak diinginkan (Hanlon \& Heitzman, 2010). Tax avoidance yang dilakukan, dikatakan tidak bertentangan dengan peraturan Undang-undang perpajakan karena dianggap praktik yang berhubungan dengan tax avoidance ini lebih memanfaatkan celah (loopholes) yang terdapat dalam peraturan perpajakan untuk menghindari pembayaran pajak yang jumlahnya lebih besar. Tax avoidance merupakan upaya untuk mengurangi hutang pajak yang bersifat legal dan aman bagi wajib pajak, tetapi kegiatan ini memunculkan risiko bagi perusahaan antara lain denda dan buruknya reputasi perusahaan dimata publik (Janjay \& Newberry, 1997).

Ada perbedaan antara penghindaran pajak (tax avoidance) dengan penggelapan pajak (tax evasion) yaitu tax evasion merupakan perilaku ilegal karena melanggar Undang-undang atau peraturan yang berlaku (Jensen \& Meckling, 1976). Pada umumnya perusahaan selalu ingin memaksimalkan labanya. Salah satu cara memaksimalkan laba yaitu dengan cara menghindari bayar pajak. Tax avoidance dilakukan dengan cara memanfaatkan celah hukum 
sehingga perusahaan tidak membayar pajak atau membayar pajak tetapi dengan beban pajak yang sangat kecil (Ayuningtyas \& Sujana, 2018).

Penerimaan pajak di Indonesia sudah direncanakan agar mencapai target yang diinginkan sesuai dengan Anggaran Pendapatan dan Belanja Negara (APBN). Berdasarkan data yang dipublikasikan oleh Kementerian Keuangan Republik Indonesia, besarnya target dan realisasi penerimaan pajak pada tahun 2015-2017, disajikan dalam Tabel 1 berikut.

\section{Tabel 1.}

Target dan Realisasi Penerimaan Pajak Tahun 2015-2017

\begin{tabular}{llll}
\hline Tahun & $\begin{array}{l}\text { Target Penerimaan } \\
\text { Pajak (Trilliun } \\
\text { Rupiah) }\end{array}$ & $\begin{array}{l}\text { Realisasi Penerimaan } \\
\text { Pajak (Trilliun } \\
\text { Rupiah) }\end{array}$ & $\begin{array}{l}\text { Persentase Realisasi } \\
\text { Penerimaan Pajak }\end{array}$ \\
\hline 2015 & 1.489 & 1.236 & 83,0 \\
2016 & 1.539 & 1.285 & 83,5 \\
2017 & 1.473 & 1.340 & 91,0 \\
\hline Sumber: Data diolah, 2019 & &
\end{tabular}

Berdasarkan Tabel 1 presentase realisasi penerimaan negara yang berasal dari sektor pajak dari tahun 2015 hingga tahun 2017 mengalami peningkatan namun belum mencapai target yang telah ditetapkan. Realisasi penerimaan negara dari sektor pajak yang meliputi semua jenis pajak pada tahun 2015 adalah sebesar 83,0 persen, tahun 2016 sebesar 83,5 persen dan tahun 2017 sebesar 91,0 persen. Belum mampunya pemerintah merealisasi penerimaan pajak secara maksimal menimbulkan pertanyaan apakah dari sisi wajib pajak badan (perusahaan) maupun pribadi terdapat praktik penghindaran pajak untuk mengurangi beban pajaknya, ataukah memang pemungutan pajak yang dilakukan belum mampu berjalan secara optimal.

Salah satu sektor yang kerap melakukan tindakan penghindaran pajak adalah sektor pertambangan. Hal tersebut terbukti pada tahun 2009 terdapat 
kasus yang terjadi pada perusahaan pertambangan batubara besar yaitu PT Kaltim Prima Coal (KPC), PT Bumi Resources Tbk. dan PT Arutmin diindikasi melakukan tindakan praktik penghindaran pajak dengan jumlah Rp.2,176 triliun, dengan rincian KPC sebagai penghindar pajak terbesar yaitu Rp.1,500 triliun, sementara Bumi Resources Rp 376 miliyar dan Arutmin sebesar Rp 300 miliyar (Tempo.co, 2010).

Kementerian Keuangan Republik Indonesia menyatakan bahwa pemerintah menyoroti masih rendahnya tingkat kepatuhan wajib pajak di bidang pertambangan mineral dan batu bara (minerba). Dari total 6.181 wajib pajak minerba, hanya 2.557 dengan presentase 41,4 persen wajib pajak yang melaporkan Surat Pemberitahuan (SPT) Tahunan, sedangkan yang tidak melaporkan mencapai 3.624 dengan presentase sebesar 58,6 persen. (Kemenkeu, 2016). Hal ini memperlihatkan bahwa tingkat kepatuhan pajak perusahaan-perusahaan pertambangan masih sangat memprihatinkan, sehingga rendahnya kepatuhan pajak mengindikasikan adanya keinginan untuk melakukan tidakan penghindaran pajak.

Ukuran perusahaan dianggap mampu mempengaruhi cara sebuah perusahaan dalam memenuhi kewajiban pajaknya dan merupakan faktor yang dapat menyebabkan terjadinya tax avoidance (Landolf, 2006). Machfoedz (1994) menyatakan bahwa ukuran perusahaan merupakan suatu skala yang dapat mengelompokkan perusahaan menjadi perusahaan besar dan kecil menurut berbagai cara seperti ukuran perusahaan bisa kita lihat melalui total aset perusahaan yang dimiliki, nilai pasar saham, rata-rata tingkat penjualan, 
dan jumlah penjualan. Semakin besar aset yang dimiliki perusahaan maka semakin besar ukuran perusahaan. Semakin besar ukuran perusahaan maka semakin menjadi pusat perhatian dari pemerintah dan akan menimbulkan kecenderungan bagi para manajer perusahaan untuk berlaku patuh dalam perpajakan (Kurniasih \& Sari, 2013). Penelitian yang dilakukan oleh Swingly (2015) menyatakan bahwa ukuran perusahaan berpengaruh positif pada tax avoidance sedangkan Rachmithasari (2015), Cheisviyanny \& Rinaldi (2015) dan (Lim, 2011) menyatakan ukuran perusahaan berpengaruh negatif pada tax avoidance.

Faktor selanjutnya yang dapat mempengaruhi perusahaan untuk melakukan tax avoidance yaitu Corporate Social Responsibility (CSR). Watson (2015) menyatakan bahwa perusahaan yang mempunyai peringkat rendah dalam Corporate Social Responsibility (CSR) dianggap sebagai perusahaan yang tidak bertanggung jawab secara sosial sehingga dapat melakukan strategi pajak yang lebih agresif dibandingkan perusahaan yang sadar sosial. Hal yang serupa diungkapkan oleh Hoi et al. (2014) perusahaan dengan kegiatan CSR yang tidak bertanggung jawab lebih agresif dalam menghindari pajak. Praktik penghindaran pajak dilihat hanya untuk meningkatkan kesejahteraan perusahaan oleh karena itu, menjadikan perusahaan dinilai tidak bertanggung jawab secara sosial. Penelitian yang dilakukan oleh Lanis \& Richardson (2011), Yoehana (2013), Minnick \& Noga (2010) dan Nugraha (2015) menyatakan bahwa CSR berpengaruh negatif terhadap penghindaran pajak. Semakin tinggi tingkat pengungkapan CSR yang 
dilakukan perusahaan maka perusahaan semakin menghindari adanya tindakan tax avoidance.

Faktor selanjutnya yang dapat mempengaruhi perusahaan untuk melakukan tax avoidance yaitu profitabilitas. Profitabilitas merupakan gambaran kinerja keuangan perusahaan dalam menghasilkan laba dari pengelolaan aktiva yang dikenal denga Retun On Assets (ROA). Semakin tinggi tingkat profitabilitas perusahaan maka semakin besar laba yang dapat dihasilkan perusahaan, sehingga pajak yang dikenakan atas laba perusahaan akan semakin besar. Hasil penelitian yang dilakukan oleh Dewi \& Noviari (2017) serta Dewinta \& Setiawan (2016) menemukan bahwa profitabilitas berpengaruh positif pada penghindaran pajak, sedangkan Maharani \& Suardana (2014) menemukan bahwa profitabilitas berpengaruh negatif terhadap tax avoidance.

Faktor selanjutnya yang dapat mempengaruhi perusahaan untuk melakukan tax avoidance yaitu leverage. Leverage adalah suatu perbandingan yang mencerminkan besarnya utang yang digunakan untuk pembiayaan oleh perusahaan dalam menjalankan aktivitas operasinya (Praditasari \& Setiawan, 2017). Semakin besar penggunaan utang oleh perusahaan, maka semakin banyak jumlah beban bunga yang dikeluarkan oleh perusahaan, sehingga dapat mengurangi laba sebelum kena pajak perusahaan yang selanjutnya akan dapat mengurangi besaran pajak yang nantinya harus dibayarkan oleh perusahaan (Subakti, 2012). Penelitian terkait dengan leverage yang dilakukan oleh Noor et al. (2010) yang menjelaskan bahwa perusahaan dengan jumlah utang lebih 
banyak memiliki tarif pajak yang efektif baik, hal ini berarti bahwa dengan jumlah utang yang banyak, perusahaan untuk melakukan tax avoidance akan cenderung lebih kecil. Hasil penelitian yang dilakukan oleh Rachmithasari (2015) menemukan bahwa leverage berpengaruh positif terhadap tax avoidance, sedangkan Swingly (2015) dan Walby (2010) menemukan bahwa leverage berpengaruh negatif pada tax avoidance.

Penelitian tentang tax avoidance semakin menarik untuk diteliti, karena penelitian mengenai faktor-faktor yang memengaruhi tax avoidance ini sudah banyak diteliti dan memiliki hasil yang berbeda-beda. Penelitian ini penting untuk membuktikan kembali terkait Pengaruh ukuran perusahaan, corporate social responsibility, profitabilitas, dan leverage pada tax avoidance. Penelitian ini mereplikasi penelitian Dewi \& Noviari (2017) yang meneliti pengaruh corporate social responsibility, profitabilitas, leverage, dan ukuran perusahaan terhadap tax avoidance pada perusahaan manufaktur yang terdaftar di Bursa Efek Indonesia (BEI) periode 2013-2015 dengan memperoleh hasil ukuran perusahaan, leverage dan pengungkapan corporate social responsibility berpengaruh negatif dan signifikan pada penghindaran pajak, sedangkan profitabilitas berpengaruh positif dan signifikan pada penghindaran pajak. Untuk membedakan penelitian ini dengan penelitian sebelumnya, peneliti menggunakan laporan tahunan (annual report) perusahaan pada periode 20152017 dan meneliti pada perusahaan pertambangan yang terdaftar di Bursa Efek Indonesia. 
Alasan peneliti memilih perusahaan pertambangan karena sektor pertambangan mempunyai pengaruh yang sangat besar terhadap perekonomian Indonesia terlebih Indonesia merupakan Negara penghasil sumber daya alam yang berpotensial, sehingga dapat dimanfaatkan untuk meningkatkan pendapatan Nasional. Perusahaan sektor pertambangan juga merupakan kelompok industry high profile, yang dalam operasionalnya bersinggungan langsung dengan kepentingan luas sehingga pasti akan menjadi perhatian bagi pemerintah, investor, maupun masyarakat dalam ketaatannya membayar pajak.

Ukuran perusahaan dapat dilihat dari kemampuan finansial suatu perusahaan. Perusahaan yang memiliki aktiva dengan jumlah yang besar dapat disebut dengan perusahaan besar. Perusahaan yang besar akan berusaha untuk mematuhi segala peraturan perpajakan yang berlaku agar mendapatkan legitimasi atau pengakuan baik dari stakeholder yaitu dengan cara membayar pajak sesuai dengan yang diharuskan sehingga perusahaan besar cenderung memiliki tarif pajak efektif yang besar yang berarti perusahaan besar akan menghindari tindakan tax avoidance karena perusahaan besar mendapat perhatian yang luas dari kalangan konsumen dan media yang nantinya akan menarik perhatian pemerintah (Zimmerman, 1983).

Penelitian yang dilakukan oleh Cheisviyanny \& Rinaldi (2015) menentukan bahwa ukuran perusahaan berpengaruh negatif pada tax avoidance. Hasil serupa juga di tunjukkan oleh Kurniasih \& Sari (2013), serta Dewi \& Jati (2014) yang menyatakan ukuran perusahaan berpengaruh negatif 
pada tax avoidance. Berdasarkan uraian diatas, maka hipotesis dalam penelitian ini adalah.

$\mathrm{H}_{1}$ : Ukuran perusahaan berpengaruh negatif pada tax avoidance.

Perusahaan dalam mempertahankan kelangsungan hidupnya selalu berupaya agar mendapatkan legitimasi atau pengakuan baik dari pemerintah, investor, kreditor, konsumen maupun masyarakat sekitar (Hidayati \& Murni, 2014). Konsep legitimasi menunjukkan adanya tanggung jawab perusahaan terhadap masyarakat. Teori legitimasi inilah yang mendasari hubungan pengungkapan CSR dengan penghindaran pajak.

Penghindaran pajak merupakan salah satu hambatan yang terjadi dalam pemungutan pajak sehingga menyebabkan berkurangnya penerimaan kas negara (Bachtiar, 2015). CSR merupakan tindakan sosial sebagai bentuk tanggung jawab sebuah perusahaan terhadap semua stakeholder nya. Berdasarkan pandangan teori legitimasi CSR merupakan salah satu cara mendapatkan legitimasi dari masyarakat, semakin tinggi tingkat pengungkapan CSR suatu perusahaan maka akan semakin tinggi juga reputasi perusahaan di mata masyarakat yang mengindikasikan perusahaan menghindari adanya tindakan tax avoidance karena perusahaan yang mengungkapkan CSR berusaha untuk membangun hubungan yang baik dengan stakeholder, baik melalui kegiatan CSR maupun dengan membayar pajak sesuai dengan kewajibannya.

Penelitian yang dilakukan oleh Lanis \& Richardson (2011), Yoehana (2013), dan Nugraha (2015) menyatakan bahwa CSR berpengaruh negatif 
terhadap penghindaran pajak. Semakin tinggi tingkat pengungkapan CSR yang dilakukan perusahaan maka perusahaan semakin menghindari tindakan tax avoidance. Berdasarkan uraian diatas, maka hipotesis dalam penelitian ini adalah.

$\mathrm{H}_{2}$ : Corporate Social Responsibility berpengaruh negatif pada tax avoidance.

Teori agensi menjelaskan hal yang mengacu para agent untuk meningkatkan laba perusahaan. Profitabilitas merupakan gambaran kinerja keuangan perusahaan dalam menghasilkan laba dari pengelolaan aktiva yang dikenal dengan Retun On Assets (ROA). ROA erat kaitanya pada laba bersih perusahaan termasuk juga pengenaan pajak penghasilan (Kurniasih \& Sari, 2013). Profitabilitas perusahaan terhadap penghindaran pajak akan memiliki hubungan positif. Jika nilai ROA tinggi, menjelasakan adanya efisiensi yang dilakukan oleh pihak manejemen. Ketika laba yang diperoleh membesar, maka jumlah pajak penghasilan akan meningkat sesuai dengan peningkatan laba perusahaan sehingga kecenderungan untuk melakukan tax avoidance yang dilakukan oleh perusahaan akan meningkat.

Hasil penelitian Cheisviyanny \& Rinaldi (2015) menunjukkan bahwa profitabilitas berpengaruh positif pada tax avoidance. Hasil serupa juga di tunjukkan oleh Maharani \& Suardana (2014) yang menyatakan profitabilitas berpengaruh positif pada tax avoidance. Berdasarkan uraian diatas, maka hipotesis dalam penelitian ini adalah.

$\mathrm{H}_{3}$ : Profitabilitas berpengaruh positif pada tax avoidance. 
I Gusti Ayu Dwi Cahya Dewanti dan I Ketut Sujana. Pengaruh ...

Leverage merupakan rasio yang menunjukan besarnya komposisi utang suatu perusahaan. Leverage menggambarkan hubungan antara total assets dengan penggunaan utang untuk meningkatkan laba dan menunjukan penggunaan utang untuk membiayai investasi (Kurniasih \& Sari, 2013). Sesuai dengan teori keagenan yaitu hubungan agen dan prinsipal, hubungan pemilik/pemegang saham (principal) dengan manajer (agent) kaitanya adalah bagaimana manjer perusahaan menggunakan hutang dalam pembiayaan kegiatan oprasional perusahaan. Apabila perusahaan menggunakan hutang pada komposisi pembiayaan, maka akan timbul beban bunga yang harus dibayar sehingga akan menjadi pengurang penghasilan kena pajak. Semakin besar hutang maka laba kena pajak akan menjadi lebih kecil karena insentif pajak atas bunga hutang yang semakin besar. Biaya bunga yang semakin tinggi akan memberikan pengaruh berkurangnya beban pajak perusahaan oleh karena itu, semakin tinggi rasio leverage maka tax avoidance yang dilakukan oleh perusahaan semakin rendah.

Hasil penelitian Noor et al. (2010) menjelaskan bahwa perusahaan dengan jumlah utang lebih banyak memiliki tarif pajak yang efektif baik, hal ini berarti bahwa dengan jumlah utang yang banyak, perusahaan untuk melakukan tax avoidance akan cenderung lebih kecil. Hal ini sejalan dengan penelitian Swingly (2015) yang menyatakan bahwa leverage berpengaruh negatif pada tax avoidance. Berdasarkan uraian diatas, maka hipotesis dalam penelitian ini adalah.

$\mathrm{H}_{4}$ : Leverage berpengaruh negatif pada tax avoidance. 


\section{METODE PENELITIAN}

Lokasi penelitian merupakan suatu tempat atau wilayah dimana penelitian tersebut dilakukan. Penelitian ini dilakukan di perusahaan pertambangan yang terdaftar di Bursa Efek Indonesia periode 2015-2017 dengan mengakses data perusahaan berupa informasi laporan keuangan pada situs resminya di www.idx.co.id.

Obyek yang digunakan pada penelitian ini adalah Ukuran Perusahaan $\left(\mathrm{X}_{1}\right)$, Corporate Social Responsibility $\left(\mathrm{X}_{2}\right)$, Profitabilitas $\left(\mathrm{X}_{3}\right)$, Leverage $\left(\mathrm{X}_{4}\right)$ dan Tax Avoidance (Y) pada perusahaan pertambangan yang terdaftar di Bursa Efek Indonesia periode 2015-2017.

Populasi yang digunakan dalam penelitian adalah seluruh perusahaan pertambangan yang terdaftar di Bursa Efek Indonesia. Teknik sampling yang digunakan dalam penelitian ini adalah nonprobability sampling, yaitu teknik pengambilan sampel yang tidak memberikan peluang atau kesempatan sama bagi setiap unsur atau anggota populasi untuk dipilih menjadi sampel.

Analisis regresi linier berganda (multiple linier regression) dapat menunjukkan arah hubungan antar variabel, digunakan untuk memecahkan rumusan masalah yang ada, atau apakah memiliki hubungan positif atau negatif. Variabel dependen dalam penelitian ini adalah tax avoidance. Variabel independen dalam penelitian ini adalah ukuran perusahaan, Corporate Social Responsibility, profitabilitas, dan leverage. Adapun model regresi linier berganda dalam penelitian ini ditunjukkan oleh persamaan berikut.

$$
Y=\alpha+\beta_{1} X_{1}+\beta_{2} X_{2}+\beta_{3} X_{3}+\beta_{4} X_{4}+\varepsilon
$$


Keterangan:

$\begin{array}{ll}\mathrm{Y} & =\text { Tax Avoidance } \\ \alpha & =\text { Nilai Konstanta } \\ \beta_{1}, \beta_{2}, \beta_{3}, \beta_{4} & =\text { Koefisien regresi } \\ \mathrm{X}_{1} & =\text { Ukuran Perusahaan } \\ \mathrm{X}_{2} & =\text { Corporate Social Responsibility } \\ \mathrm{X}_{3} & =\text { Profitabilitas } \\ \mathrm{X}_{4} & =\text { Leverage } \\ \varepsilon & =\text { Error }\end{array}$

\section{HASIL DAN PEMBAHASAN}

Hasil uji statistik deskriptif masing-masing variabel dalam penelitian ini dapat dilihat dalam Tabel 2 berikut:

Tabel 2.

Hasil Uji Statistik Deskriptif

\begin{tabular}{lrrrrr}
\hline & $\mathrm{N}$ & Minimum & \multicolumn{1}{c}{ Maximum } & \multicolumn{1}{c}{ Mean } & Std. Deviation \\
\hline Ukuran Perusahaan & 39 & 11,782 & 13,966 & 12,70447 & 0,555663 \\
CSR & 39 & 0,011 & 0,549 & 0,13384 & 0,108811 \\
Profitabilitas & 39 & 0,001 & 0,394 & 0,10554 & 0,096715 \\
Leverage & 39 & 0,015 & 0,620 & 0,37639 & 0,128268 \\
Tax Avoidance & 39 & 0,101 & 0,994 & 0,41480 & 0,237837 \\
Valid N (listwise) & 39 & & & & \\
\hline Sumber: Data dina & & & & &
\end{tabular}

Sumber: Data diolah, 2019

Berdasarkan Tabel 2 dapat dijelaskan bahwa variabel terikat tax avoidance yang diproksikan dengan CETR pada perusahaan sektor pertambangan yang terdaftar di BEI tahun 2015-2017 memiliki nilai minimum sebesar 0.101 dan nilai maksimum sebesar 0.994. CETR memiliki nilai ratarata sebesar 0.41480 yang artinya bahwa nilai CETR yang tergolong tinggi dan mengindikasikan rendahnya tindakan tax avoidance didalam perusahaan. Nilai standar deviasi sebesar 0.237837 , hal ini berarti adanya penyimpangan data terhadap nilai rata-ratanya sebesar 0.237837 dan menunjukkan hasil penyebaran data yang normal dan tidak menyebabkan bias. 
Variabel bebas ukuran perusahaan yang diproksikan dengan log total aset pada perusahaan pertambangan yang terdaftar di BEI periode 2015-2017 memiliki nilai minimum sebesar 11.782 dan nilai maksimum sebesar 13.966 . Variabel ukuran perusahaan memiliki rata-rata sebesar 12.70447 yang lebih kearah median atau tengah-tengah yang artinya bahwa perusahaan sektor pertambangan seimbang antara yang berukuran kecil dan berukuran besar. Standar deviasi sebesar 0.555663 , hal ini berarti adanya penyimpangan data terhadap nilai rata-ratanya sebesar 0.555663 dan menunjukkan hasil penyebaran data yang normal dan tidak menyebabkan bias.

Variabel bebas selanjutnya yaitu CSR yang diproksikan dengan CSRDI pada perusahaan pertambangan yang terdaftar di BEI periode 2015-2017 memiliki nilai minimum sebesar 0.011 dan nilai maksimum sebesar 0.549 . CSRDI memiliki rata-rata sebesar 0.13384 yang lebih mendekati nilai minimum yang artinya bahwa perusahaan yang dijadikan sampel lebih sedikit mengungkapkan CSR. Standar deviasi sebesar 0.108811, hal ini berarti adanya penyimpangan data terhadap nilai rata-ratanya sebesar 0.108811 dan menunjukkan hasil penyebaran data yang normal dan tidak menyebabkan bias.

Variabel bebas selanjutnya yaitu profitabilitas yang diproksikan dengan ROA pada perusahaan pertambangan yang terdaftar di BEI periode 2015-2017 memiliki nilai minimum sebesar 0.001 dan nilai maksimum sebesar 0.394 . ROA memiliki rata-rata sebesar 0.10554 yang lebih mendekati nilai maksimum yang artinya bahwa perusahaan memeroleh laba yang cukup tinggi. Standar deviasi sebesar 0.096715 , hal ini berarti adanya penyimpangan data terhadap 
nilai rata-ratanya sebesar 0.096715 dan menunjukkan hasil penyebaran data yang normal dan tidak menyebabkan bias.

Variabel bebas yang terakhir yaitu leverage yang diproksikan dengan DAR pada perusahaan pertambangan yang terdaftar di BEI periode 2015-2017 memiliki nilai minimum sebesar 0.015 dan nilai maksimum sebesar 0.620 . DAR memiliki rata-rata sebesar 0.37639 yang lebih mendekati nilai maksimum yang artinya bahwa perusahaan banyak menggunakan tingkat hutang untuk mendanai kegiatan operasionalnya. Standar deviasi sebesar 0.128268 , hal ini berarti adanya penyimpangan data terhadap nilai rata-ratanya sebesar 0.128268 dan menunjukkan hasil penyebaran data yang normal dan tidak menyebabkan bias.

Hasil dari analisis regresi linier berganda dapat dilihat pada Tabel 3 berikut.

Tabel 3.

Hasil Analisis Regresi Linier Berganda

\begin{tabular}{|c|c|c|c|c|c|c|}
\hline \multirow{2}{*}{\multicolumn{2}{|c|}{ Model }} & \multicolumn{2}{|c|}{$\begin{array}{l}\text { Unstandardized } \\
\text { Coefficients }\end{array}$} & \multirow{2}{*}{$\begin{array}{c}\text { Standardized } \\
\text { Coefficients } \\
\text { Beta } \\
\end{array}$} & \multirow[b]{2}{*}{$\mathrm{t}$} & \multirow[b]{2}{*}{ Sig. } \\
\hline & & $\mathrm{B}$ & Std. Error & & & \\
\hline \multirow[t]{6}{*}{1} & (Constant) & 0,619 & 0,802 & & 0,772 & 0,446 \\
\hline & Ukuran & 0,003 & 0,065 & 0,006 & 0,040 & 0,969 \\
\hline & Perusahaan & & & & & \\
\hline & CSR & $-0,718$ & 0,345 & $-0,329$ & $-2,082$ & 0,045 \\
\hline & Profitabilitas & $-1,000$ & 0,387 & $-0,407$ & $-2,581$ & 0,014 \\
\hline & Leverage & $-0,094$ & 0,319 & $-0,051$ & $-0,294$ & 0,770 \\
\hline
\end{tabular}

Sumber: Data diolah, 2019

Berdasarkan Tabel 3 diperoleh suatu persamaan regresi sebagai berikut:

$$
\mathrm{Y}=0,619+0,003 \mathrm{X}_{1}-0,718 \mathrm{X}_{2}-1,000 \mathrm{X}_{3}-0,094 \mathrm{X}_{4}
$$

Nilai konstanta ( $\alpha$ ) 0,619 menunjukkan bahwa apabila Ukuran Perusahaan $\left(\mathrm{X}_{1}\right)$, CSR $\left(\mathrm{X}_{2}\right)$, Profitabilitas $\left(\mathrm{X}_{3}\right)$, dan Leverage $\left(\mathrm{X}_{4}\right)$ sama dengan nol, maka nilai CETR (Y) adalah sebesar 0,619. 
Nilai Koefisien $\beta_{1}=0,003$ menunjukkan bahwa jika nilai Ukuran Perusahaan $\left(\mathrm{X}_{1}\right)$ naik 1 satuan, maka nilai CETR (Y) akan naik sebesar 0,003 satuan dengan asumsi variabel lainnya konstan.

Nilai Koefisien $\beta_{2}=-0,718$ menunjukkan bahwa jika nilai CSR $\left(\mathrm{X}_{2}\right)$ naik 1 satuan, maka nilai CETR (Y) akan turun sebesar 0,718 satuan dengan asumsi variabel lainnya konstan.

Nilai Koefisien $\beta_{3}=-1,000$ menunjukkan bahwa jika nilai Profitabilitas $\left(\mathrm{X}_{3}\right)$ naik 1 satuan, maka nilai CETR (Y) akan turun sebesar 1,000 satuan dengan asumsi variabel lainnya konstan.

Nilai Koefisien $\beta_{4}=-0,094$ menunjukkan bahwa jika nilai Leverage $\left(\mathrm{X}_{4}\right)$ naik 1 satuan, maka nilai CETR (Y) akan turun sebesar 0,094 satuan dengan asumsi variabel lainnya konstan.

Uji koefisien determinasi $\left(\mathrm{R}^{2}\right)$ bertujuan untuk mengetahui dan mengukur kemampuan model dalam menerangkan variansi variabel dependen. Peneliti menggunakan nilai adjusted $\mathrm{R}^{2}$ pada saat mengevaluasi yang mana model regresi terbaik, karena nilai adjusted $\mathrm{R}^{2}$ dapat naik atau turun apabila satu variabel independen ditambahkan ke dalam model. Hasil koefisien determinasi dapat dilihat pada Tabel 4 berikut.

Table 4.

Hasil Koefisien Determinasi

\begin{tabular}{lrrrr}
\hline Model & R & R Square & Adjusted R Square & Std. Error of the Estimate \\
\hline 1 & $0,543^{\mathrm{a}}$ & 0,295 & 0,212 & 0,21113363 \\
\hline
\end{tabular}

Sumber: Data diolah, 2019

Berdasarkan Tabel 4 dapat dilihat bahwa nilai Adjusted $R$ Square pada model sebesar 0,212. Nilai Adjusted $R$ Square pada model artinya variabel Tax avoidance dapat dijelaskan oleh variabel Ukuran Perusahaan, CSR, 
Profitabilitas, dan Leverage sebesar 21,2 persen, sedangkan sisanya sebesar 78,8 persen dijelaskan oleh variabel lain diluar model. Standar Error of the Estimate (SEE) sebesar 0,21, yang artinya semakin kecil nilai SEE akan membuat model regresi semakin tepat dalam memprediksi variabel independen.

Uji kelayakan model regresi bertujuan untuk mengetahui apakah semua variabel bebas yang diidentifikasi (ukuran perusahaan, corporate social responsibility, profitabilitas dan leverage) tepat digunakan memprediksi tax avoidance. Hasil uji kelayakan model (uji F) dapat dilihat pada Tabel 5 sebagai berikut.

Tabel 5.

Hasil Uji Kelayakan Model

\begin{tabular}{llrrrrr}
\hline Model & & Sum of Squares & Df & Mean Square & F & Sig. \\
\hline 1 & Regression & 0,634 & 4 & 0,158 & 3,555 & $0,016^{\mathrm{a}}$ \\
& Residual & 1,516 & 34 & 0,045 & & \\
& Total & 2,150 & 38 & & & \\
\hline
\end{tabular}

Sumber: Data diolah, 2019

Berdasarkan Tabel 5 dapat dilihat bahwa pada model memiliki nilai Sig. sebesar 0,016 lebih kecil dari $\alpha=0,05$, menunjukkan model penelitian ini layak untuk digunakan sebagai alat analisis untuk menguji pengaruh variabel independen terhadap variabel dependen. Hal ini berarti bahwa variabel Ukuran Perusahaan, CSR, Profitabilitas, dan Leverage berpengaruh secara bersamasama terhadap variabel dependennya yaitu Tax avoidance.

Uji hipotesis dilakukan untuk mengetahui pengaruh suatu variabel bebas yang terdiri dari ukuran perusahaan $\left(\mathrm{X}_{1}\right), \mathrm{CSR}\left(\mathrm{X}_{2}\right)$, profitabilitas $\left(\mathrm{X}_{3}\right)$, dan leverage $\left(\mathrm{X}_{4}\right)$ secara individual menerangkan variasi variabel terikat yaitu 
tax avoidance yang di proksikan dengan CETR (Y). Hasil uji statistik t dapat dilihat pada Tabel 6 sebagai berikut.

Tabel 6. Hasil Uji Hipotesis

\begin{tabular}{lcccc}
\hline \multicolumn{1}{c}{ Variabel } & $\begin{array}{c}\text { Koefisien } \\
\text { Regresi }\end{array}$ & $\mathrm{t}_{\text {hitung }}$ & Sig. & Hasil Hipotesis \\
\hline Ukuran Perusahaan (X1) & 0,003 & 0,040 & 0,969 & $\mathrm{H}_{1}$ Ditolak \\
CSR (X2) & $-0,718$ & $-2,082$ & 0,045 & $\mathrm{H}_{2}$ Diterima \\
Profitabilitas (X3) & $-1,000$ & $-2,581$ & 0,014 & $\mathrm{H}_{3}$ Ditolak \\
Leverage (X4) & $-0,094$ & $-0,294$ & 0,770 & $\mathrm{H}_{4}$ Ditolak \\
\hline Sumber: Data diolah, 2019 & & &
\end{tabular}

Hipotesis pertama menyatakan bahwa Ukuran Perusahaan berpengaruh negatif pada Tax avoidance. Pada Tabel di atas dapat dilihat bahwa nilai signifikansi uji t untuk variabel Ukuran Perusahaan sebesar 0,969 yaitu lebih besar dari $\alpha=0,05$ dengan koefisien regresi bernilai positif sebesar 0,003 . Berdasarkan hal tersebut, maka hipotesis pertama $\left(\mathrm{H}_{1}\right)$ dalam penelitian ini ditolak. Artinya Ukuran Perusahaan tidak berpengaruh pada Tax avoidance.

Hipotesis kedua menyatakan bahwa CSR berpengaruh negatif pada Tax avoidance. Pada Tabel di atas dapat dilihat bahwa nilai signifikansi uji t untuk variabel CSR sebesar 0,045 yaitu lebih kecil dari $\alpha=0,05$ dengan koefisien regresi bernilai negatif sebesar -0,718. Berdasarkan hal tersebut, maka hipotesis kedua $\left(\mathrm{H}_{2}\right)$ dalam penelitian ini diterima. Artinya CSR berpengaruh negatif pada Tax avoidance.

Hipotesis ketiga menyatakan bahwa Profitabilitas berpengaruh positif pada Tax avoidance. Pada Tabel di atas dapat dilihat bahwa nilai signifikansi uji t untuk variabel Profitabilitas sebesar 0,014 yaitu lebih kecil dari $\alpha=0,05$ dengan koefisien regresi bernilai negatif sebesar -1,000. Berdasarkan hal 
tersebut, maka hipotesis ketiga $\left(\mathrm{H}_{3}\right)$ dalam penelitian ini ditolak. Artinya Profitabilitas berpengaruh negatif pada Tax avoidance.

Hipotesis keempat menyatakan bahwa Leverage berpengaruh negatif pada Tax avoidance. Pada Tabel di atas dapat dilihat bahwa nilai signifikansi uji t untuk variabel Leverage sebesar 0,770 yaitu lebih besar dari $\alpha=0,05$ dengan koefisien regresi bernilai negatif sebesar -0,094. Berdasarkan hal tersebut, maka hipotesis ketiga $\left(\mathrm{H}_{3}\right)$ dalam penelitian ini ditolak. Artinya Leverage tidak berpengaruh pada Tax avoidance.

Hipotesis pertama $\left(\mathrm{H}_{1}\right)$ menyatakan bahwa ukuran perusahaan berpengaruh negatif pada tax avoidance. Hasil analisis pada tablel 6 menunjukkan bahwa nilai koefisien positif sebesar 0,003 dengan tingkat signifikansi 0,969 lebih besar dari taraf nyata dalam penelitian yaitu $\alpha=0,05$ yang artinya bahwa ukuran perusahaan tidak berpengaruh pada tax avoidance.

Hal ini berarti hasil penelitian ini tidak berhasil membuktikan berlakunya teori legitimasi sebagai teori yang mendasari penelitian ini yang mengatakan bahwa perusahaan yang besar akan berusaha untuk mematuhi segala peraturan perpajakan yang berlaku agar mendapatkan legitimasi atau pengakuan baik dari stakeholder yaitu dengan cara membayar pajak sesuai dengan yang diharuskan sehingga perusahaan besar cenderung memiliki tarif pajak efektif yang besar yang berarti perusahaan besar akan menghindari tindakan tax avoidance karena perusahaan besar mendapat perhatian yang luas dari kalangan konsumen dan media yang nantinya akan menarik perhatian pemerintah. 
Ukuran perusahaan dikatakan tidak berpengaruh pada tax avoidance karena besar kecilnya suatu perusahaan yang diukur melalui total aset yang dimiliki tidak memengaruhi keputusan perusahaan untuk melakukan tindakan tax avoidance. Perusahaan juga tidak ingin mengambil risiko atas tindakan tax avoidance yang mungkin dilakukan karena hal tersebut akan berdampak pada citra perusahaan. Jadi perusahaan dengan ukuran yang besar maupun kecil sama-sama patuh terhadap peraturan perpajakan yang berlaku sehingga akan berdampak positif untuk perusahaan di waktu yang akan datang. Hasil penelitian ini sejalan dengan hasil penelitian sebelumnya yang dilakukan oleh Rachmithasari (2015) serta Merslythalia \& Lasmana (2016) yang telah membuktikan bahwa ukuran perusahaan tidak berpengaruh pada tax avoidance.

Hipotesis kedua $\left(\mathrm{H}_{2}\right)$ menyatakan bahwa corporate social responsibility (CSR) berpengaruh negatif pada tax avoidance. Hasil analisis pada tablel 6 menunjukkan bahwa nilai koefisien negatif sebesar $-0,718$ dengan tingkat signifikansi 0,045 lebih kecil dari taraf nyata dalam penelitian yaitu $\alpha=0,05$ yang artinya bahwa CSR berpengaruh negatif pada tax avoidance.

Tingkat aktivitas CSR yang tinggi cenderung semakin tinggi pula sikap tanggung jawab yang dimiliki perusahaan dicerminkan dalam sikap patuhnya dalam membayar beban pajak yang telah ditetapkan atau tidak melakukan penghindaran pajak. Aktivitas CSR merupakan suatu tindakan yang tidak hanya memperhitungkan ekonomi tetapi juga sosial, lingkungan dan dampak lain dari tindakan yang dilakukan perusahaan sendiri sebagai bentuk tanggung jawab kepada para stakeholder. 
I Gusti Ayu Dwi Cahya Dewanti dan I Ketut Sujana. Pengaruh ...

Sesuai dengan teori legitimasi yang menyatakan bahwa perusahaan dalam mempertahankan kelangsungan hidupnya selalu berupaya agar mendapatkan legitimasi atau pengakuan baik dari para stakeholder nya. Semakin tinggi tingkat pengungkapan CSR yang dilakukan perusahaan maka perusahaan semakin menghindari adanya tindakan tax avoidance karena perusahaan yang mengungkapkan CSR berusaha untuk membangun hubungan yang baik dengan stakeholder, baik melalui kegiatan CSR maupun dengan membayar pajak sesuai dengan kewajibanya. Hasil penelitian ini sejalan dengan hasil penelitian yang dilakukan oleh Yoehana (2013) dan Nugraha (2015) yang menyatakan bahwa CSR berpengaruh negatif terhadap penghindaran pajak.

Hipotesis ketiga $\left(\mathrm{H}_{3}\right)$ menyatakan bahwa profitabilitas berpengaruh positif pada tax avoidance. Hasil analisis pada tablel 6 menunjukkan bahwa nilai koefisien negatif sebesar -1,000 dengan tingkat signifikansi 0,014 lebih kecil dari taraf nyata dalam penelitian yaitu $\alpha=0,05$ yang artinya bahwa profitabilitas berpengaruh negatif pada tax avoidance.

Hal ini berarti hasil penelitian ini tidak berhasil membuktikan berlakunya teori agensi sebagai teori yang mendasari penelitian ini yang mengatakan bahwa teori agensi akan memacu para agent untuk meningkatkan laba perusahaan agar mendapatkan imbalan yang besar. Ketika laba yang diperoleh perusahaan membesar maka jumlah pajak penghasilan badan juga akan meningkat sesuai dengan jumlah laba yang diperoleh perusahaan 
sehingga kemungkinan perusahaan untuk melakukan penghindaran pajak untuk menghindari peningkatan jumlah beban pajak.

Profitabilitas dikatakan berpengaruh negatif pada tax avoidance karena perusahaan dengan tingkat profitabilitas yang tinggi menunjukkan keadaan perusahaan yang memiliki laba yang tinggi atau memiliki kecukupan dalam pembayaran pajak. Perusahaan meyakini dengan memiliki laba yang tinggi perusahaan mampu membayar pajak sesuai dengan aturan perundanganundangan yang berlaku tanpa harus melakukan kegiatan penghindaran pajak. Perusahaan yang memiliki perencanaan pajak yang baik maka akan memperoleh pajak yang optimal, hal tersebut berakibat kecederungan perusahaan melakukan penghindaran pajak akan menurun. Hasil penelitian ini sejalan dengan hasil penelitian sebelumnya yang telah dilakukan oleh Utari \& Supadmi (2017) serta Nugrahitha \& Bambang Suprasto (2018) dimana mereka telah membuktikan bahwa profitabilitas berpengaruh negarif pada tax avoidance.

Hipotesis keempat $\left(\mathrm{H}_{4}\right)$ menyatakan bahwa leverage berpengaruh negatif pada tax avoidance. Hasil analisis pada tablel 6 menunjukkan bahwa nilai koefisien negatif sebesar -0,094 dengan tingkat signifikansi 0,770 lebih besar dari taraf nyata dalam penelitian yaitu $\alpha=0,05$ yang artinya bahwa leverage tidak berpengaruh pada tax avoidance.

Hal ini berarti hasil penelitian ini tidak berhasil membuktikan berlakunya teori agensi sebagai teori yang mendasari penelitian ini yang mengatakan bahwa sesuai dengan teori keagenan yaitu hubungan 
I Gusti Ayu Dwi Cahya Dewanti dan I Ketut Sujana. Pengaruh ...

pemilik/pemegang saham (principal) dengan manajer (agent) adalah bagaimana manjer perusahaan menggunakan hutang dalam pembiayaan kegiatan oprasional perusahaan. Semakin besar hutang maka laba kena pajak akan menjadi lebih kecil karena insentif pajak atas bunga hutang yang semakin besar. Biaya bunga yang semakin tinggi akan memberikan pengaruh berkurangnya beban pajak perusahaan oleh karena itu, semakin tinggi rasio leverage maka tax avoidance yang dilakukan oleh perusahaan semakin rendah.

Leverage dikatakan tidak berpengaruh pada tax avoidance karena semakin tinggi tingkat hutang suatu perusahaan, maka tidak akan memengaruhi adanya praktik tax avoidance. Pihak manajemen akan lebih berhati-hati dan tidak akan mengambil risiko yang tinggi untuk melakukan aktivitas penghindaran pajak guna untuk menekan beban pajaknya. Apabila hutang digunakan dalam jumlah yang besar maka dapat menimbulkan kerugian bagi perusahaan itu sendiri, sehingga perusahaan tidak ingin mengambil risiko dengan melakukan kegiatan tax avoidance. Hasil penelitian ini sejalan dengan hasil penelitian yang telah dilakukan oleh Dewinta (2016) dan Moses (2017) dimana mereka telah membuktikan bahwa leverage tidak berpengaruh terhadap tax avoidance.

Penelitian ini mendapatkan simpulan bahwa CSR berpengaruh negatif pada tax avoidance. Hal ini mendukung teori legitimasi yang menyatakan bahwa perusahaan dalam mempertahankan kelangsungan hidupnya selalu berupaya agar mendapatkan legitimasi atau pengakuan baik dari para stakeholder nya. Semakin tinggi tingkat pengungkapan CSR yang dilakukan 
perusahaan maka perusahaan semakin menghindari adanya tindakan tax avoidance karena perusahaan yang mengungkapkan CSR berusaha untuk membangun hubungan yang baik dengan stakeholder, baik melalui kegiatan CSR maupun dengan membayar pajak sesuai dengan kewajibanya.

Penelitian ini juga membuktikan bahwa tidak semua variabel dapat memengaruhi tax avoidance sesuai dengan teori. Ukuran perusahaan dan leverage tidak berpengaruh pada tax avoidance sedangkan profitabilitas berpengaruh negatif pada tax avoidance. Hal ini tidak sesuai dengan teori legitimasi yang menjadi dasar untuk menentukan hipotesis pengaruh ukuran persahaan pada tax avoidance dan hal ini juga tidak sesuai dengan teori agensi yang menjadi dasar untuk menentukan hipotesis pengaruh leverage dan profitabilitas pada tax avoidance.

Hasil penelitian ini secara praktis dapat digunakan sebagai masukan bagi perusahaan yang diteliti untuk lebih memerhatikan setiap keputusan yang akan diambil serta risiko yang akan ditanggung dari setiap keputusan yang dibuat sesuai dengan undang-undang dan peraturan perpajakan yang berlaku agar terhindar dari sanksi perpajakan yang dapat merugikan perusahaan. Bagi pemerintah, penelitian ini dapat menjadi pertimbangan dalam membuat regulasi terkait perpajakan dan tindakan penghindaran pajak yang dilakukan perusahaan. 
I Gusti Ayu Dwi Cahya Dewanti dan I Ketut Sujana. Pengaruh ...

\section{SIMPULAN}

Ukuran Perusahaan tidak berpengaruh pada tax avoidance. Besar kecilnya suatu perusahaan yang diukur memlaui total aset yang dimiliki tidak memengaruhi keputusan perusahaan untuk melakukan tindakan tax avoidance.

Corporate Social Responsibility berpengaruh negatif pada tax avoidance. Semakin tinggi aktivitas CSR suatu perusahaan semakin perusahaan patuh membayar pajak atau tidak melakukan tindakan tax avoidance.

Profitabilitas berpengaruh negatif pada tax avoidance. Semakin tinggi nilai profitabilitas perusahaan maka kecenderungan perusahaan melakukan tindakan tax avoidance semakin rendah.

Leverage tidak berpengaruh pada tax avoidance. Semakin tinggi tingkat hutang suatu perusahaan, maka tidak akan memengaruhi adanya praktik tax avoidance.

Bagi perusahaan diharapkan agar tetap memperhatikan dan meningkatkan aktivitas CSRnya. Hal ini nantinya dapat memberikan pengaruh yang positif bagi perusahaan dan juga dapat meningkatkan citra perusahaan di mata pubik.

Bagi peneliti selanjutnya diharapkan agar mengembangkan penelitian dengan menambahkan variabel lain yang mungkin mempengaruhi tindakan tax avoidance misalnya terkait komite audit, kualitas audit, dan komisaris independen. Penelitian yang dilakukan oleh Eksandy, (2017) telah membuktikan bahwa komisaris independen, komite audit dan kualitas audit berpengaruh signifikan terhadap tax avoidance. 


\section{REFERENSI}

Ayuningtyas, N. P. W., \& Sujana, I. Ketut. (2018). Pengaruh Proporsi Komisaris Independen, Leverage, Sales Growth, Dan Profitabilitas Pada Tax Avoidance. E-Jurnal Akuntansi Universitas Udayana, 25, 18841912.

Bachtiar, M. D. (2015). Pengaruh Struktur Kepemilikan, Ukuran Perusahaan , dan Capital Intensity terhadap Effective Tax Rate (ETR). Jurnal Akuntansi. Fakultas Ekonomika dan Bisnis Universitas Diponegoro, 1-52.

Cheisviyanny, C., \& Rinaldi. (2015). Pengaruh Profitabilitas , Ukuran Perusahaan Dan Kompensasi Rugi Fiskal Terhadap Tax Avoidance ( Studi Empiris Pada Perusahaan Manufaktur Yang Terdaftar Di BEI Tahun 2010-2013 ). Seminar Nasional Ekonomi Manajemen Dan Akuntansi (Snema) Fakultas Ekonomi Universitas Negeri Padang.

Chen, S., Chen, X., Cheng, Q., \& Shevlin, T. (2010). Are family firms more tax aggressive than non-family firms? Journal of Financial Economics. https://doi.org/10.1016/j.jfineco.2009.02.003

Darmawan, I. G. H., \& Sukartha, I. M. (2014). Pengaruh Penerapan Corporate Governance, Leverage, Return On Assets dan Ukuran Perusahaan pada Penghindaran Pajak. E-Jurnal Akuntansi Universitas Udayana, 9(1), 143161.

Darmayanti, P. P. B. (2019). Pengaruh Ukuran Perusahaan , Profitabilitas, Koneksi Politik dan Pengungkapan Corporate Social Responsibility Pada Tax Avoidance. E-Jurnal Akuntansi Universitas Udayana, 26, 19922019.

Dewi, N. L. P. P., \& Noviari, N. (2017). Pengaruh Ukuran Perusahaan, Leverage, Profitabilitas dan Corporate Social Responsibility Terhada Tax Avoidance. E-Jurnal Akuntansi Universitas Udayana, 21(1), 830-859.

Dewi, N. N. K., \& Jati, I. K. (2014). Pengaruh Karakter Eksekutif, Karakteristik Perusahaan, Dan Dimensi Tata Kelola Perusahaan Yang Baik Pada Tax Avoidance Di Bursa Efek Indonesia. E-Jurnal Akuntansi Universitas Udayana, 6(2), 249-260

Dewinta, I. A. R., \& Setiawan, P. E. (2016). Pengaruh Ukuran Perusahaan, Umur Perusahaan, Profitabilitas, Leverage, Dan Pertumbuhan Penjualan Terhadap Tax Avoidance. E-Jurnal Akuntansi Universitas Udayana, 14(3), 1584-1613.

Dowling, J., \& Pfeffer, J. (1975). Organizational Legitimacy: Social Values 
and Organizational Behavior. The Pacific Sociological Review. https://doi.org/10.2307/1388226.

Dyreng, S. D., Hanlon, M., \& Maydew, E. L. (2008). Long-Run Corporate Tax Avoidance. The Accounting Review, 83(1), 61-82.

Eksandy, A. (2017). Pengaruh Komisaris Independen, Komite Audit dan Kualitas Audit Terhadap Penghindaran Pajak. E-Jurnal Akuntansi Universitas Muhammadiyah, $\mathrm{Vol}$ 1, No 1.

Hanlon, M., \& Heitzman, S. (2010). A review of tax research. Journal of Accounting and Economics. https://doi.org/10.1016/j.jacceco.2010.09.002.

Hidayati, N. N., \& Murni, S. (2014). Pengaruh Pengungkapan Corporate Social Responsibility Terhadap Earningss Response Coefficient Pada Perusahaan High Profile. E-Jurnal Akuntansi Universitas Udayana, 11(1), 1-18.

Hoi, C.-K., Wu, Q., \& Zhang, H. (2014). Is Corporate Social Responsibility (CSR) Associated with Tax Avoidance? Evidence from Irresponsible CSR Activities. Journal of Animal and Plant Sciences. https://doi.org/10.2308/accr-50544.

Janjay, Gupta., \& Newberry, Kaye. (1997). Determinants of the Variability in Corporate Effective Tax Rates : Evidence from Longitudinal Data. Journal of Accounting and Public Policy, 16, 1-34.

Jensen, M. C., \& Meckling, W. H. (1976). Managerial behavior, agency costs and ownership structure. Journal of Financial Economics. https://doi.org/DOI: 10.1016/0304-405X(76)90026-X

Kemenkeu. (2016). Pemerintah Soroti Rendahnya Kepatuhan Wajib Pajak Minerba dan Migas. https://www.kemenkeu.go.id. Diakses 30 Oktober 2018.

Kementerian Keuangan Republik Indonesia, 2019.

Kurniasih, T., \& Sari, M. M. R. (2013). Pengaruh Return On Assets, Leverage, Corporate Governance, Ukuran Perusahaan, Dan Kompensasi Rugi Fiskal Pada Tax Avoidance. Buletin Studi Ekonomi, 18(1), 58-66. https://doi.org/10.1016/j.giq.2005.05.002

Landolf, U. (2006). Tax and Corporate Responsibility. International Tax Review.

Lim, Y. (2011). Tax avoidance, cost of debt and shareholder activism: 
Evidence from Korea. Journal of Banking and Finance. https://doi.org/10.1016/j.jbankfin.2010.08.021.

Lanis, R., \& Richardson, G. (2011). The effect of board of director composition on corporate tax aggressiveness. Journal of Accounting and $\begin{array}{llll}\text { Public } \quad \text { Policy, } & 30 & \text { (1), }\end{array}$ https://doi.org/10.1016/j.jaccpubpol.2010.09.003.

Machfoedz, M. (1994). Financial Ratio Characteristic Analysis and The Prediction of Earnings Changes in Indonesia (Kelola 7).

Maharani, I. G. A. C., \& Suardana, K. A. (2014). Pengaruh Corporate Governance , Profitabilitas Dan Karakteristik Eksekutif Pada Tax Avoidance Perusahaan Manufaktur. E-Jurnal Akuntansi Universitas Udayana, 9(2), 525-539.

Merslythalia, D. R., \& Lasmana, M. S. (2016). Pengaruh Kompetensi Eksekutif, Ukuran Perusahaan, Komisaris Independen dan Kepemilikan Institusional Terhadap Tax Avoidance. Jurnal Ilmiah Akuntansi Dan Bisnis, 11(2), 117-124.

Minnick, K., \& Noga, T. (2010). Do corporate governance characteristics influence tax management? Journal of Corporate Finance. https://doi.org/10.1016/j.jcorpfin.2010.08.005

Moses D. R. S. (2017). Pengaruh Profitabilitas, Leverage, dan Corporate Governance Terhadap Tax Avoidance. Jurnal Skripsi. Sekolah Tinggi Ilmu Ekonomi Indonesia.

Noor, R. M., Fadzillah, N. S. M., \& Mastuki, N. (2010). Corporate Tax Planning: A Study On Corporate Effective Tax Rates of Malaysian Listed Companies. International Journal of Trade, Economics and Finance. https://doi.org/10.7763/IJTEF.2010.V1.34

Nugraha, N. B. (2015). Pengaruh Corporate Social Responsibility, Ukuran Perusahaan, Profitabilitas, Leverage dan Intensity terhadap Agresivitas Pajak (Studi Empiris pada Perusahaan Non Keuangan yang Terdaftar di Bursa Efek Indonesia 2012-2013). Diponegoro Journal of Accounting.

Nugrahitha, I. M. A., \& Bambang Suprasto, H. (2018). Pengaruh Profitabilitas, Leverage , Corporate Governance, dan Karakter Eksekutif pada Tax Avoidance. E-Jurnal Akuntansi Universitas Udayana, 22(3), 2016-2039.

Praditasari, N. K. A., \& Setiawan, P. E. (2017). Pengaruh Good Corporate Governance, Ukuran Perusahaan, Leverage Dan Profitabilitas Pada Tax Avoidance. E-Jurnal Akuntansi Universitas Udayana, 19(3), 1229-1258. 
Rachmithasari, A. F. (2015). Pengaruh Return On Assets, Leverage, Corporate Governance, Ukuran Perusahaan dan Kompensasi Rugi Fiskal Pada Tax Avoidance (Perusahaan Manufaktur yang Terdaftar di Bursa Efek Indonesia Tahun 2011-2013 ). Jurnal Universitas Surakarta. Fakultas Ekonomi Dan Bisnis, Universitas Muhammadiyah Surakarta.

Sari, G. M. (2014). Pengaruh Corporate Governance, Ukuran Perusahaan, Kompensasi Rugi Fiskal Dan Struktur Kepemilikan Terhadap Tax Avoidance. Jurnal WRA.

Subakti, T. A. V. (2012). Pengaruh karakteristik perusahaan dan reformasi perpajakan terhadap penghindaran pajak pada Perusahaan Industri Manufaktur yang terdaftar di Bursa Efek Indonesia tahun 2008- 2010. Jurnal Akuntansi. Fakultas Ekonomi Dan Bisnis Universitas Indonesia.

Swingly, C. (2015). Pengaruh Karakteristik Eksekutif, Komite audit, dan Ukuran Perusahaan, Leverage, dan Sales Growth pada Tax Avoidance. EJurnal Akuntansi Universitas Udayana, 10(1), 47-62.

Tempo.co.2010. Jalan Panjang Kasus Pajak KPC. https://bisnis.tempo.co/. Diakses 30 Oktober 2018.

Utari, N. K. Y., \& Supadmi, N. L. (2017). Pengaruh Corporate Governance, Profitabilitas dan Koneksi Politik Pada Tax Avoidance. E-Jurnal Akuntansi Universitas Udayana, 18(3), 2202-2230.

Walby, K. (2010). What is the difference between statutory, average, marginal and effective tax rates? Journal. hhtp:www.fairtax.org/PDF/What-Is-TheDifference-Between-Tax-Rates.pdf. Diakses pada tanggal 30 Oktober 2018.

Watson, L. (2015). Corporate Social Responsibility, Tax Avoidance, and Earnings Performance. The Journal of the American Taxation Association. https://doi.org/10.2308/atax-51022

Yoehana, M. (2013). Analisis Pengaruh Corporate Social Responsibility Terhadap Agresivitas Pajak. Skripsi Universitas Diponegoro. https://doi.org/10.1590/S0102-47442007000100019

Zimmerman, J. L. (1983). Taxes and firm size. Journal of Accounting and Economics. https://doi.org/10.1016/0165-4101(83)90008-3. 